\title{
Subarachnoid-pleural fistula-case report and review of literature
}

\author{
NORMAN SHANNON, BRIAN KENDALL, DGT THOMAS, H BAKER \\ From the Department of Neurological Surgery, National Hospital for Nervous Diseases, Maida Vale, \\ London, UK
}

SUMMARY The investigation and surgical closure of a subarachnoid pleural fistula following direct trauma to the dorsal spinal theca and spinal cord are described and a review of the literature on spinal subarachnoid-pleural fistula is presented.

Direct or indirect trauma to the chest wall and dorsal spinal column may result rarely in a fistulous connection between the pleural space and the subarachnoid space. The detection and localisation of this kind of fistula is challenging. In this paper a case of subarachnoid-pleural fistula is described and by reference to the previously reported eleven cases attention is drawn to several problems peculiar to the management of this clinical entity.

\section{Case report}

A 27-year-old male Indonesian sustained several stab wounds in the chest, resulting in his emergency admission to a surgical thoracic unit where the knife was found to be still in situ; no additional injuries were noted. At thoracotomy the knife was removed and about $1 \frac{1}{2}$ litres of clotted blood evacuated from the pleural cavity. It then proved very difficult to control bleeding which was coming from the spine so that a laminectomy and costo-trasversectomy were performed and revealed a tear in the dura and pia arachnoid. The bleeding was controlled and the dura closed. Although the patient made an otherwise uneventful recovery he developed signs of a complete cord lesion at the D4 level.

In the course of investigation for pyrexia, in a rehabilitation unit, a large left pleural effusion was noted, with no evidence of pneumothorax. Repeated aspiration as well as a short period of pleural drainage failed to clear the blood stained sterile fluid. Detailed biochemical

Address for reprint requests: Dr B Kendall, National Hospital, Queen Square, London WC1N 3BG, UK.

Received 4 June 1981 and in revised form 13 November 1981 Accepted 9 December 1981 analysis of the aspirate, including electrophoresis, failed to establish the presence of CSF in the transudate. The patient was transferred to a neurosurgical unit with a tentative diagnosis of subarachnoid pleural fistula.

Plain radiographs of the spine and chest revealed bony defects due to the surgery and a left sided pleural effusion. Metrizamide myelography showed atrophy of the upper dorsal spinal cord and irregularity of the theca at D4 level (fig a, b). There was no obstruction and, despite elective positioning, no leakage of contrast medium from the theca could be recognised. A CT scan, performed about 3 hours after the myelogram confirmed the cord atrophy. The pleural fluid at this time was of relatively high density (50 HU), which finding is compatible with contamination by a small amount of metrizamide, but could also be caused by blood and protein in the effusion. A myelogram was performed using $\mathrm{Tc}^{99}$ which revealed immediate extension of radioactivity laterally from the left side of the theca at D4 level followed by high radioactivity in the left pleural cavity (fig c, d).

\section{Treatment}

The theca was widely exposed at the previous level of trauma using an anterolateral approach and on entering the pleural cavity there was an efflux of serosanguineous fluid. After opening the dura, sharp and blunt dissection revealed a fistulous opening in the dura mater anteriorly and to the left of the midline through which a Jacques catheter was easily passed into the pleural cavity. The fistulous track was then completely opened and adhesions between the lung and parietal pleura were freed. Closure of the fistula and dura was effected using silk sutures with surgical laid along the suture line. A pleural cavity drain was inserted and wound closure was performed in a routine manner. Recovery was uneventful without additional neurological deficit and no recurrence of the pleural effusion. 


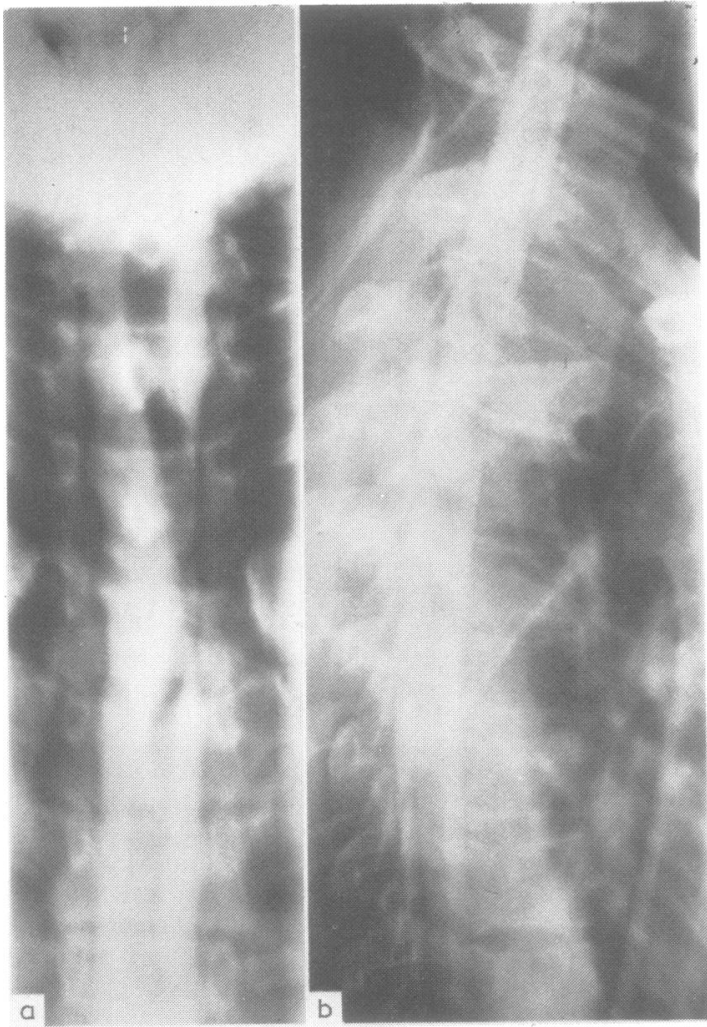

Figure Metrizamide myelogram: (a) anteroposterior. (b) lateral projection lower cervical and thoracic regions. The upper dorsal spinal cord is atrophic. It is deviated to the left side at D4 level where the margins of the subarachnoid space are irregular due to arachnoidal adhesions.

Figure Isotype myelogram after lumbar

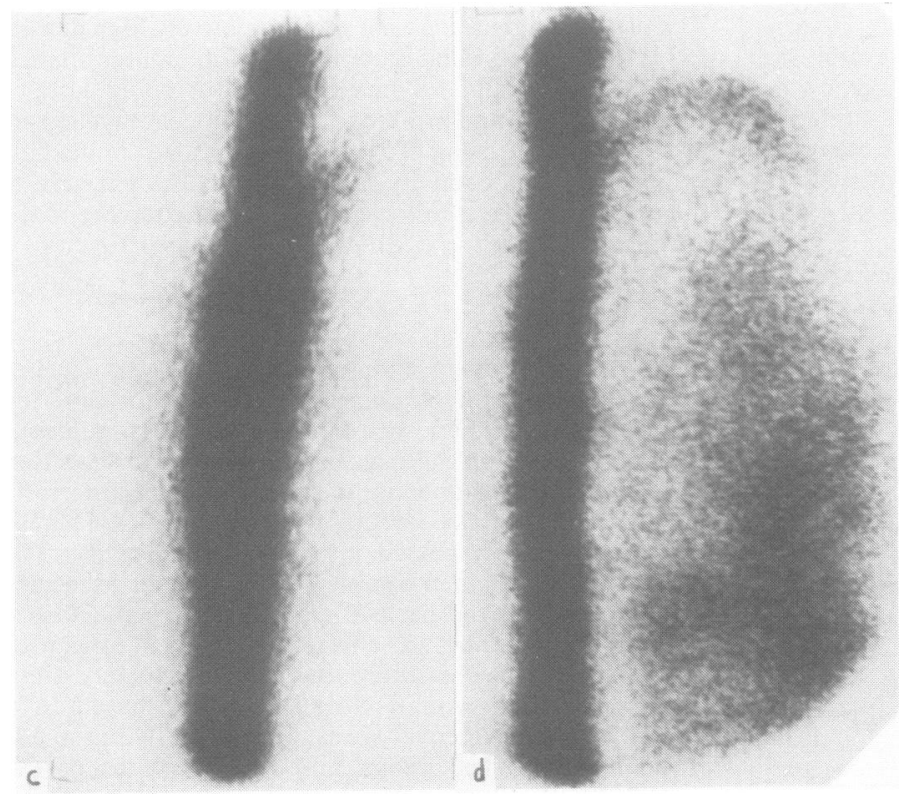
injection of Tc ${ }^{99}$ EDTA: (c) immediate scan. Isotope delineates the spinal subarachnoid space and leaks from the upper dorsal theca into the left paravertebral region. (d) scan $2 h$ later. The leak extending into the left pleural cavity is clearly shown. 
Table Summary of reported cases

\begin{tabular}{|c|c|c|c|c|c|c|c|}
\hline Reference & $\begin{array}{l}\text { Age } \\
(y r)\end{array}$ & $\operatorname{Sex}$ & Injury & $\begin{array}{l}\text { Duration } \\
\text { of fistula }\end{array}$ & $\begin{array}{l}\text { Initial neurological } \\
\text { deficit }\end{array}$ & $\begin{array}{l}\text { Diagnostic } \\
\text { procedure }\end{array}$ & Method of fistula closure \\
\hline Molloy et $a l^{3}$ & 19 & $\mathbf{M}$ & $\begin{array}{l}\text { Thoraco-abdominal } \\
\text { gunshot wound }\end{array}$ & 8 months & $\begin{array}{l}\text { Complete Cord } \\
\text { lesion at D7 } \\
\text { (CCLD7) }\end{array}$ & $\begin{array}{l}\text { At operation. } \\
\text { Myelogram not } \\
\text { performed }\end{array}$ & Myopleural flap \\
\hline $\begin{array}{l}\text { Wilson et al" } \\
\text { Overton et } a^{5}\end{array}$ & $\begin{array}{l}28 \\
22\end{array}$ & $\begin{array}{l}\mathbf{M} \\
\mathbf{F}\end{array}$ & $\begin{array}{l}\text { Automobile accident } \\
\text { Automobile accident }\end{array}$ & $\begin{array}{l}7 \text { hours } \\
6 \text { years }\end{array}$ & $\begin{array}{l}\text { CCLD7 } \\
\text { Incomplete Cord } \\
\text { lesion D6 }\end{array}$ & $\begin{array}{l}\text { Myelogram } \\
\text { Myelogram }\end{array}$ & $\begin{array}{l}\text { Closure with muscle } \\
\text { Closure with muscle }\end{array}$ \\
\hline Branwit et al" & 42 & $\mathbf{M}$ & $\begin{array}{l}\text { Gunshot chest } \\
\text { wound }\end{array}$ & 2 days & CCLD7 & Myelogram & Spontaneous closure \\
\hline Zilka et al $^{7}$ & 4 & $\mathbf{M}$ & $\begin{array}{l}\text { Fall four floors } \\
\text { against a fence }\end{array}$ & 12 hours & CCLD3 & Myelogram & Laminectomy D3. Suture closure of dura \\
\hline Cantus & 15 & $\mathbf{F}$ & Automobile accident & 24 hours & CCLD4 & Myelogram & $\begin{array}{l}\text { Bilateral chest drains } \\
\text { Laminectomy D2-D5. Suture of dura }\end{array}$ \\
\hline Higgins et al" & 7 & $\mathbf{M}$ & Automobile accident & 7 days & CCLD3 & Operation & $\begin{array}{l}\text { Laminectomy. Gelatinsoaked in } \\
\text { thrombin }\end{array}$ \\
\hline $\begin{array}{l}\text { Rocha Campos } \\
\text { et } a l^{1}\end{array}$ & 5 & $\mathbf{M}$ & Automobile accident & 8 hours & CCLD1 & $\begin{array}{l}\text { Tc 99EDTA } \\
\text { Myelogram }\end{array}$ & Closure with muscle \\
\hline Hofstetter et al ${ }^{10}$ & 43 & $\mathbf{M}$ & $\begin{array}{l}\text { Resection of } \\
\text { bronchogenic } \\
\text { carcinoma adherent } \\
\text { to spinal column }\end{array}$ & 2 months & None & Myelogram & Laminectomy D3-D5. Suture of dura \\
\hline $\begin{array}{l}\text { de Pinto et } \text { al }^{11} \\
\text { Beutel }^{2}\end{array}$ & $\begin{array}{r}5 \\
27\end{array}$ & $\begin{array}{l}\mathbf{F} \\
\mathbf{M}\end{array}$ & $\begin{array}{l}\text { Automobile accident } \\
\text { Thoraco-abdominal } \\
\text { gunshot wound }\end{array}$ & $\begin{array}{l}17 \text { days } \\
4 \text { months }\end{array}$ & $\begin{array}{l}\text { CCLD1 } \\
\text { CCLD7 }\end{array}$ & $\begin{array}{l}\text { Myelogram } \\
\text { Radionucleide } \\
\text { cisternal myelogram }\end{array}$ & $\begin{array}{l}\text { Pleuralaspiration by suction drain } \\
\text { Thoracoplasty-excision of } R(1-4) \text { ribs. } \\
\text { Dura sutured }\end{array}$ \\
\hline This case & 28 & $\mathbf{M}$ & Stab wound to chest & 2 months & None & $\begin{array}{l}\text { RHISA myelogram } \\
\text { Myelogram }\end{array}$ & Muscle and methacrylate \\
\hline
\end{tabular}

\section{Discussion}

This case is the first reported in which such a posttraumatic fistula was caused by a stab wound and is only the 12th recorded due to any cause. The table summarises in chronological order the clinical features of this case and the other reported cases.

Each of the cases shares the common history of trauma to the chest wall and spinal column with associated radiological evidence of bone damage and haemothorax or haemopneumothorax, but unlike previously documented cases our patient had no neurological deficit prior to surgical exploration. The presence of a post-traumatic pleural effusion, which fails to clear after repeated aspiration, is not commonly caused by subarachnoid pleural fistula. However, it should be strongly suspected after infection and traumatic pancreatitis have been excluded. In only one instance has spontaneous closure of a subarachnoid-pleural fistula been recorded, and so early localisation and closure of the fistula should be the objective rather than a conservative approach. It is important to appreciate that chemical analysis of the pleural fluid may not allow identification of CSF because of admixture with transudate from the pleural epithelium, despite earlier observations ${ }^{1}$ which describe the pleural fluid as having the composition of blood stained CSF. Two months after the injury in our case the fluid still contained red cells and a high protein content. However, Beutel et $a l^{2}$ described the fluid from the pleural cavity in their cases two months after injury as being "a crystal clear transudate free of cells with normal glucose, chloride and protein".

The detection of a subarachnoid-pleural fistula can best be achieved by the methods described below. A dye such as indigo-carmine ${ }^{2}$ may be injected intrathecally, and if it leaks out into the pleural cavity it may be recovered by pleural aspiration. However, in the case described by Beutel et $a l^{2}{ }^{2}$ there was no leakage of dye although a fistula was eventually detected by other means. Furthermore intrathecal dye does not allow the site of the fistula to be accurately localised. In ideal circumstances myelography will demonstrate both the anatomy in the region of trauma and the site of the fistula. The present case is the first recorded in which water soluble contrast medium was used. If leakage of CSF is intermittent, myelography may only demonstrate thecal irregularity or stenosis at the site of trauma, or signs of arachnoiditis. Also with slow rates of leakage there may be insufficient opacification to show the fistula on conventional x-ray films. In such a case it might be shown by CT soon after the metrizamide myelogram or the presence, but not the site, may be ascertained by detecting iodine within the pleural fluid. Isotope myelography is particularly useful in cases, such as the one described here, where metrizamide myelography fails to demonstrate the leak. This is because an appropriate isotope can be detected in minute concentrations by means of intermittent study over several hours if necessary, and thus a minimal leak may be demonstrated. In all three recorded cases in which isotope myelography has been used the fistula has been shown. Isotope studies also demonstrate any intrathecal 
spinal obstruction but have the disadvantage compared to conventional and computed myelography of not providing a detailed image of the anatomy at the fistula site.

The following routine of investigation is therefore suggested. Plain radiographs and computed tomography can be used to show the anatomy in the region of trauma and to allow the density of the pleural fluid to be measured. Subsequently, water soluble myelography may be used to demonstrate the anatomy of the subarachnoid space at the site of trauma. The fistula may be shown clearly by this study but computed tomography following the myelogram may show it in more detail, and reveal a small or poorly opacified fistula, which has not been detected by the conventional study; any increase in the density of the pleural fluid will also be revealed. If the fistula is not demonstrated isotope myelography should be performed. Failure of the isotope study to demonstrate a fistula should lead to a decision whether to observe for several weeks and then repeat investigations if the leak persists or else to go ahead with a major exploratory procedure at the site of trauma.

The aim of surgical treatment can be simply stated as closure of the fistula ensuring that the cord is not damaged. The procedure requires meticulous dissection and the laying open of the fistula track. When the two epithelial surfaces comprising the fistula lining have been separated its closure can be achieved using nonabsorbable materials. There is no conclusive evidence that the use of myopleural flaps or methacrylate has any advantage over simple suture closure of the fistula.

\section{References}

${ }^{1}$ Rocha Campos BA, Silva LB, Negrao MM. Traumatic subarachnoid pleural fistula. J Neurol Neurosurg Psychiatry 1974;37:269-70.

2 Beutel EW, Roberts JD, Langston HT, Barker WL. Subarachnoid-pleural fistula. J Thorac Cardiovasc Surg 1980;80:21-4.

${ }^{3}$ Milloy FJ, Correll NO, Langston HT. Persistent subarachnoid pleural fistula. JAMA 1959;169: 14679.

4 Wilson C, Jumer M. Traumatic spinal pleural fistula. JAMA 1962;179:812-3.

${ }^{5}$ Overton MC, Hoad RM, Farris RG. Traumatic subarachnoid-pleural fistula. J Thorac Cardiovasc Surg 1966;51:729-31.

- Branwit DN, Schmelka DD. Traumatic subarachnoidpleural fistula. Radiology 1967;89:737-8.

'Zilkha A, Reiss J, Schulman K, Schecter MM. Traumatic subarachnoid-mediastinal fistula. $J$ Neurosurg 1970;32:473-5.

${ }^{8}$ Cantu RC. Value of myelography in thoracic spinal cord injuries. Int Surg 1971;56:23-6.

${ }^{2}$ Higgins CB, Mulder DG. Traumatic subarachnoidpleural fistula. Chest 1972;61:189-90.

${ }^{10}$ Hofstetter KR, Bjelland JC, Patton DD, Woolfenden JM, Henry RE. Detection of broncho-pleural subarachnoid fistula by radionucleide myelography. Case report. J Nucl Med 1977;18:981-3.

11 De Pinto D, Payne T, Kittle CF. Traumatic subarachnoid-pleural fistula. Ann Thorac Surg 1978;25:477-8. 